\title{
MARX'S CONCEPT OF MAN IN MUSLIM SCHOLARS PERSPECTIVE
}

\author{
Ilyas Daud \\ UIN Sunan Kalijaga Yogyakarta \\ yasirselebes@gmail.com

\section{Bermawy Munthe} \\ UIN Sunan Kalijaga Yogyakarta \\ bermawymunthe@yahoo.com
}

\author{
Ahmad Baidhowi \\ UIN Sunan Kalijaga Yogyakarta \\ baidowi@hotmail.com
}

\section{Abstract}

This paper analyzed the human concept according to Marxism, wich is based on matter and separated from the transcendent elements. This Marxism thought is analyzed in an Islamic perspective represented by a group of Muslim philosophers and mufasir. The results showed that the main different and criticism of Marxism is his thinking that humanity is the result of his own creation based on materials. This refers to the idea of man-centered, autonomous, physical-biological man, without sou. Human life depends on maerials, it does not depend on things which are supernatural like God so that man must be united with nature. Marx's view of man is very different from the concept of man according to Muslim thinkers. According to them, man was created by his Lord and deeply connected with God. Besides they have physical elements, humans also have elements of the soul or nafs which very dependent on God. Humans made the Khalifah to control nature as a medium of worship to God.

Keywords: Human, Marxisme, Muslim 


\section{Abstrak}

Tulisan ini mengkaji konsep manusia menurut Marxisme yang berbasis materi dan lepas dari unsur transenden. Pemikiran Marxisme ini dilihat dari perspektif Islam yang diwakili oleh kelompok filosof muslim dan mufasir. Hasil penelitian menunjukkan bahwa perbedaan dan kritik utama terhadap Marxisme adalah pemikirannya yang melihat manusia sebagai hasil ciptaannya sendiri dengan berbasis pada materi. Hal ini mengacu pada gagasan tentang manusia berpusat pada manusia (mancentered), yang otonom, manusia fisik-biologis, tanpa ruh atau jiwa. Manusia hidup sangat bergantung pada materi, bukan pada hal-hal yang sifatnya adikodrati seperti Tuhan. Untuk itu manusia harus menyatu dengan alam. Pandangan Marx tentang manusia ini sangat berbeda dengan konsep manusia menurut pemikir muslim. Menurut mereka, manusia diciptakan oleh Tuhannya dan sangat berhubungan dengan Tuhan. Selain memiliki unsur jasmani, manusia juga memiliki unsur jiwa atau nafs yang sangat bergantung pada Tuhan. Manusia dijadikan khalifah untuk mengendalikan alam sebagai media beribadah kepada Tuhan.

Kata kunci: Manusia, Marxisme, Muslim.

\section{A. Introduction}

Humans are always interesting to be studied. Even today the knowledge of humans grows and develops. Various aspects and forms of human circumstances are examined systematically by various sciences, especially in the field of philosophy. Besides philosophy, the most distinctive elements of man are analyzed by social science, cultural anthropology, history, psychology, and jurisprudence. However, few of the field of knowledge which studied can touch the most fundamental aspect of human beings. ${ }^{1}$

Related to human nature, M. Sastrapratedja states that man is a creature of history. Human beings are historical in case that they become themselves through their relationship to nature and the environment. As historical beings, then they must be placed in the trajectory of history, namely the history of the human race. ${ }^{2}$ His Marxism as an understanding which derived from the teachings of Karl Marx, understanding human history formed by its productivity. As a natural being, man in all his history, his development was born from the activity of production. Therefore,

${ }^{1}$ Anton Bakker, Antropologi Metafisik, (Yogyakarta: Penerbit Kanisius, 2000), p. 11

${ }^{2} \mathrm{M}$. Sastrapratedja, Manusia, Teka-Teki yang Mencari Solusi, edt: A. Setyo Wibowo (Yogyakarta: Penerbit Kanisius, 2009), p. 5 
human beings must be historic and interpreted as a creature that creates history through its relationship with nature in its production activities, not just creatures across history. ${ }^{3}$

This paper was made because of the reading of material-based Marxist concepts and out from the transcendent elements, including in view of human beings. In this case, Marxism's thinking about humans will be very interesting when it is viewed from the perspective of human concept according to Muslim figures both from among Muslim philosophers and among exegetes (Mufasir). From some literatures which disclose and discusse this theme, no single study has specifically focused its discussion on how far human concepts of Marxism are viewed from the perspective of Muslim thinkers. The literature has been concerned only with the concept of man separately, both from the concept of Marxism and from the concept of Muslim thinkers. The concept of Marxism for example is discussed by some literatures such as Erich Fromm in his book Marx's Concept of Man. Anthony Giddens in his book "Capitalism and Modern Social Theory, An analysis of Karl Marx's writings, Durkheim, Max Weber", 4 and AndiMuawiyahRamli in his book "The Map of Karl Max's Thought".

Philosophical approach was used in this research. The philosophical approach is intended to investigate and think deeply by emphasizing the fundamental structures and basic ideas of the object under study, in this case the concept of Man according to Marxism and Muslim thinkers. The philosophical approach also contains an element of description as an explicit discussion and a new understanding of the research results. Descriptive model is intended as an effort to describe the terms and statements regularly, so that researchers can perform a conceptual examination of the meaning in it. ${ }^{6}$ As a contribution to the science development, the most important results of this paper are to add and enrich the treasures of Islamic science in term of interconnection and integration as expected and inflated so far. Because, this paper combines three disciplines of science, namely religion, social, and philosophy.

${ }^{3}$ Firdaus Achmad, "Marxisme dan Islam, Bagaimana Manusia diperikan?" on jurnal Khatulistiwa-Journal of Islamic Studies, Volume 3, Nomor 2, (September 2013), p. 156-157

${ }^{4}$ Anthony Giddens, Kapitalisme dan teori Sosial Modern (Jakarta: UI-Press, 2007)

${ }^{5}$ Andy Muawiyah Ramli, Peta Pemikiran Karl Marx, Materialisme Dialektis dan Materialisme Historis, (Yogyakarta: Lkis, 2004)

${ }^{6}$ Anton Bekker \& Achmad Charis Zubair, Metodologi Penelitian Filsafat, (Yogyakarta: Kanisius, 2000), p. 54, 61 and 74 


\section{B. Marx's Concept of Man}

According to Karl Marx, man is the starting point and the purpose of his thought. This is what underlies the next thought. Marx's understanding of man is always closely linked to his social relationship. It will appear more clearly in his thinking, where the alignment between individual and community interests is greatly emphasized. ${ }^{7}$ Starting from Marx's view of a concrete human being, he changed the old philosophical thinking of materialism which he called highly contemplative. According to his theory, the reality of human senses should be understood as a subject in practical activity, so that reality is not merely an understanding of the object. Marx sees that "Subjective" as a cluster of social collective experiences in a struggle which happens throughout society development. The element of the object is not simply removed but obtains its philosophical place in the revolutionary spirit of the workers. Therefore, the integration of human beings as subjects and objects leads to a revolutionary praxis spirit which is called as changing the social issues. ${ }^{8}$ According to Marx, as long as humans do not eliminate the dull factor of objectivity and know themselves and their life behind fixed forms of things and laws, then this world becomes strange and wrong world. When man finally wins this self-awareness, it means he is heading not only to his own righteousness, but also to the truth of the world. With this introduction, the process continues. Humans will try to put this truth in every attitude and action and create the world into essential fulfillment of self-consciousness. ${ }^{9}$

Karl Marx in his philosophical thoughts was strongly influenced by Hegel and Feuerbach. But all of them eventually become the starting point for him to come to his own thoughts. It will appear in Marx's understanding of the human individual as described below: ${ }^{10}$

${ }^{7}$ Baskara T. Wadaya, SJ, Marx Muda, Marxisme berwajah Manusia, (Yogyakarta: Buku Baik, 2003), p. 24

${ }^{8}$ C.A. Van Peuresen, Licham-Ziel-Geest, Inleiding tot een Wijsgerige Antropologie. Trans. Dick Hatoko. Tubuh Jiwa Roh, Sebuah Pengantar dalam filsafat Manusia (Jakarta: BPK Gunung Mulia, 1981), p. 59.

${ }^{9}$ Erich Fromm, Konsep Manusia Menurut Marx, Judul asli: Marx's Concept of Man, trans. Agung Prihantoro, (Yogyakarta: Pustaka Pelajar, 2002), p. 36

${ }^{10}$ Baskara T. Wadaya, SJ, Marx Muda... p. 24-28 


\section{Individuals as part of nature}

Karl Marx with the concept of materialism, it understands human beings as natural beings and rejects every concept of man as a supernatural, supernatural being. As natural human beings are part of nature. As a part of human nature, man has a strong relationship with the world. ${ }^{11}$

The man of his own will initiates, regulates, and controls the act of reproducing materials between himself and nature. He opposes himself to nature as one of his own strengths, arrangements in the movement of hands and feet, head and hands, natural strength of body, in order to produce accordingly with a form which harmonized with his own passion. Thus, that which he works outside and change it, he actuallh at the same time he changes his own nature. ${ }^{12}$

This type of man which is accepted by Marx, and it is not idealistic men. The man according to him is a man who has a concrete, objective, and it is not one who has an abstract body. With this understanding it can be said that Marx has actually participated in the demystification of Hegel's idea of man. Although his understanding of humans is heavily influenced by Feuerbach, Marx has his own further and more original insights. According to him, Feuerbach has given a lot of contributions in the understanding of concrete man, but he forgets one thing, namely the interconnection of humans as individuals with their society.

In his criticism on Feuerbach, Marx says that Feuerbach talks only about man as a biological being who has a personal love and friendship but he forgets the social aspect of the individual in his relationship with society. Thus, Feuerbach's understanding about human world is a contemplative understanding, ignoring the role of human action in creating the world. As a result, Feuerbach's materialism is incapable dealing with social problems in human life.

There are two basic ideas underlying the critique of Marx, namely the social involvement of individuals in their social communities, and the world as a result of human activity. Marx strongly emphasizes the involvement of individuals in society. According to him, human existence can not be separated from its social context. The man in the eyes of Marx is social being. An understanding which only emphasizes man as a biological being is

${ }^{11}$ Karl Marx, Capital: A Critical Analysis of Capitalis Production Vol. I (Moscow: Foreign Langues Pubishing House, 1959), p. 177

${ }^{12}$ Ibid., 
inadequate, man has distinctive socio-historical characteristics, according to the historical stages and social classes in which he lives. Therefore, Marx understands the individual in social relation is a form of history change. ${ }^{13}$

Marx further said that human beings are the product of society as well as the creator of society. Therefore, man is a social individual. As a product of society, man is the result of a historical development. It does not mean that Marx simply repeats Aristotle's phrase that man is a zoon political, but he rather emphasizes that man in his life always depends on society. Without society, human can not survive. Marx more bravely argues that as a product of society it means society is what makes man as it is. The idea that these individuals are good ideas has a relationship with nature or their relationship to each other or their own constitution. ${ }^{14}$ The importance of this social relation became one of Marx's criticisms of capitalism which forms bourgeois economists. This type of system tends to study the relationship between commodity exchange and not knowing the relationship between materials which really reveals the social relationship between humans. ${ }^{15}$

2. Individuals as a result of his own creation

Marx's third understanding of man is that man is the product of his own creation. The view of the human as part of nature and part of society refers to a man-centered, autonomous outlook from supernatural influences. If man is not influenced by the supernatural factors, and thus not created by something which overcomes man, then who created man? Marx replied, human himself. Man creates himself through his productive activities, namely working.

Marx's thinking is based on his understanding of human beings as individuals who not only think and reason, but also work consciously and reasonably. Work is the basic form of human activity. Through working, humans change the reality of a natural world into reality which more human. Through human labor, it internalizes itself, changing the environment in which it exists and ultimately transforms itself as a biological being. Thus, the process of human creation is a process of self-creation. With his work,

${ }^{13}$ Carol C. Gould, Marx’s Social Ontologi, (New York: The Massachutsetts Institute of Technology, 1978), p. 3. 1957), p. 73.

${ }^{14}$ Marx dan Engels, on Religion (Moscow: Foreign Langues Publishinng House,

${ }^{15}$ Karl Marx, On Economis, ed. Robert Freedman, (Victoria, Penguin Books, 1962), p. 50 . 
man does not only create the conditions he needs to create life, but also creates himself.

That is why Marx rejects the views of contemplative materialists who forget humans as subject which creates. Such materialism only sees that the environment creates human beings. In fact, according to Marx, what really happens is that human beings who change and create themselves. It seems clear that Marx rejects the concept of theocentrism that says man is created by something which supernatural. Marx understands that man can survive if he has a productive power in himself, to understand the world outside of himself by expressing his special human capabilities and being able to understand the world with power and ability. Unproductive human beings are passive and repressive receptive people; in fact, he is not there and dies. In this production process, man manifests his own essence, he returns to his essence, which in theological terms means he returns to God. ${ }^{16}$

Potential of human, according to Marx, it is a potential that is taken for granted; today's human beings, as ancient human beings, are raw materials, human and irreversible materials, since their brain structure remains the same from the beginning of history. Humans change throughout history; he develops himself; he transforms himself; he is a product of history. History is the history of man's manifestation; history is nothing more than the creation of the human self through the process of work and production; "as whole of what is called the history of the world is nothing but the creation of man by the labor force, and the creation of nature for man; therefore, man has an undeniable proof of his own creation, of his own origin," ${ }^{17}$

Based on Marx's opinion, people are characterized with the principle of movement, and it should be noted that Marx quotes the opinion of a great mystic, Jakob Boeheme, dealing with this problem. The principle of movement can not be understood mechanically, but as motion, creative vitality and energy; human desire, for Marx, "is essential human power which pushes toward its goal energetically".

The concept of different productivity with the concept of receptivity can be understood more easily when we know how Marx applied it to the phenomenon of love. "he wrote, human beings can be human and their relationships with the world into human relations, then love can only be

\footnotetext{
${ }^{16}$ Erich Fromm, Konsep Manusia..., h. 39.

${ }^{17}$ Ibid., h. 35.
} 
replaced with love, trust with faith, etc. If we want to influence other, we must be people who really have a stimulating influence and enthusiasm for other, and every relationship we have with other and with nature must be a special expression relating to the purpose of our desires, the real purpose of our personal life. If we love without arousing love, ie if we can not, by manifesting ourselves as lovers, make ourselves as loved one, so that our love becomes dull and miserable. Marx also specifically expresses the significance of love between men and women as a direct connection between men.

In human relationship as a species with nature is a direct relationship among human beings, and such human relationship is a direct connection with nature or with its own natural functions. So, in this visible relation, which is reduced to a fact that can be observed, is the extent that man has become human to himself. From this relationship, the level of development of all humans can be valued. The development begins from the nature of this relationship, how far a human being has become, and understands himself as a species, a human being. The man relationship with women is the most natural relationship among human beings. Therefore, this relation shows how far his natural attitudes have become humanistic, and how far human essence has become natural essence for himself. This relationship also shows how far human needs become humanistic needs, and consequently how far other people as human beings have become one of his needs, and how far he is in his individual existence and at the same time social beings. ${ }^{18}$

The concept of activity according to Marx is very important to understand the relationship between subject and object. Human feelings, as far as wild animals, have only limited meaning. "For a hungry man, there is no humanistic form of food, but only an abstract feature of food, this food can also be in the most abusive form, and it is impossible to say why this food activity is different from the animal feeding activity which should be filled carefully, lacks appreciation of a most beautiful show. "The feeling that man possesses, say, it is naturally formed by the object outside of that feeling. This object can only be aligned with one of the faculty of man. Because not only five senses, but there are also called as spiritual senses, the practical senses (lust, love, etc.), the sensibility and human senses can only exist through the existence of the object, through the humanized nature. According to Marx, "harmonize and manifest the human individuality". The character in which these objects become dependent on the nature of the object and related

${ }^{18}$ Ibid., h. 40-42. 
faculty; the different character of each faculty is its essence and it is also its distinctive objective mode that is real and objective human being. Therefore, this character is only thought, but through all the senses, human beings are affirmed in an objective world." 19

Regarding human nature, Marx explains the idea that qua human is a known entity. Humans can be understood as human beings, not only in their biological, or anatomical and physical elements but also for their psychological elements. Of course, Marx is not tempted to assume that temperament is identical with a specific statement of human nature prevailing in a particular society. Marx says, "To know what is useful to dogs, we must understand the nature of dogs, but the dog's own character is not inferred from the benefit principle. Same as humans, anyone who will criticize all movement, behavior, human relationships and so on, must first understand the human nature in general, and then study the human nature that has been modified in every period of history.It is needed to consider consider about this idea of human nature, according to Marx, it is not an abstraction thing. This concept is the essence of man, contrary to various the historical existence of man and the essence of man is not an inherent abstraction in any separate individual. ${ }^{20}$

On the other hand, human as an individual out of the social ties of society must be understood as thinking that contrast with the essence of history, man can only be known when he is placed in relation to society, because man is nothing but whole of his relation to society. In summary, man finds his position in social collectivity. Although Feuerbach views the mind as a reflection of material reality, but Marx sees it as a non-praxical materialism because it ignores the political thing of revolutionary activity. This thought leads to a further thesis that the old metarialism is the establishment of civil society (bourgeois), whereas new materialism is a humanistic society or a socialized society. Thus, human beings as social beings are formulated in the integration of theory and praxis, and precisely at this point where the philosophical map is described. ${ }^{21}$

Marx argues that humans are creatures with social relation. $\mathrm{He}$ strongly affirmed that human nature is intertwined with the relationship of society. Therefore, human nature is not static, but must rely depend on the

${ }^{19}$ Ibid., h. 42.

${ }^{20}$ Ibid., h. 33-34.

${ }^{21}$ Cf. Alfred G. Mayer, Marxisme: The Unity of Theory and Practice (Cambridge: Harvard University Press, 1954), h. 1-5. 
context of social history, because man is shaped by dialectical opposition which understood by Marx as the founder of human history.

The conception of human nature that does not involve social and historical factors is a mistake, but considering it is also not the same with without using thing as the elements of basic concepts of human behavior. But the most important is the way the nature is adapted to each stage of history. Nevertheless, Marx believes in human nature. Our understanding of nature necessitates how society can be changed, but the most important of Marx's ideas is, his belief in how society can be changed. The real question is not whether humanity has a basic or natural character, but what kind of character human beings have is not opened to historical processes. ${ }^{22}$

\section{Muslim Scholar's Concept of Human}

In this part, it is discussed about human according to Muslim thinkers who are based on the values of Islamic teachings. They are represented by two groups, namely groups of Muslim philosophers and groups of exegetes (Mufasir).

1. Muslim philosophers

Muslim philosophers who understand human beings based on Islamic values here include al-Ghazali. According to him human figure consists of two different elements, namely body and soul. The body is material and the soul is immaterial. According to him, man is not really a physical body, but a soul. Al-Ghazali understood that the human soul proceeds through three stages: al-nafs al-nabawiyat (plant soul), al-nafs alhayawaniyat (animal soul), and al-nafs al-insaniyah (human soul). Al-nafs al-insaniyah is indeed the human soul and soul that distinguishes it from other beings. ${ }^{23}$

This division of the human soul brings al-Ghazali to the point of understanding that the physical body of man is merely an instrumental element. The substance of man is his al-nafs or his immaterial soul. This understanding is built on the principle that absolute perfection is only God. God is an immaterial substance and therefore is not limited by time and

${ }^{22}$ George Ritzer,Douglas J.Goodman, Teori Sosiologi, dari Teori Sosiologi Klasik Sampai Perkembangan Mutakhir Teori Post Modern, terj. Nurhadi, (Yogyakarta: Kreasi Wacana, 2008), p. 50-52.

${ }^{23}$ Al-Gazālī, Mizan al-'Amal, (Kairo: Dār al-Ma’ārif, 1961), p. 27. 
space. Al-Ghazali sees the perfection of reason and intuition as the primary factor in the formation of true human beings. ${ }^{24}$

It is based on his thinking that al-nafs as the substance of the man and understands the potential of reason and intuitive as the true potential power of human. Improving sense function must be accompanied by self-cleansing of material life. This material life gives birth to the mashiat and pollutes the al-nafs or human soul. Mashiat derived from fulfillment human body. The self-cleansing exercise of this material leads to al-nafs at the level where the human soul leads to God as the real purpose of life.

Cleansing of soul from this material is an attempt to foster moral awareness in man. Al-Ghazali strongly emphasized the obligation to practice the obligation of God's command. Because in nature, the nature of man is tauhid, or can not be separated from God. Tauhid is the most perfect knowledge of God. ${ }^{25}$

Besides al-Ghazali, another Muslim philosopher who talks about it is Ibn Sina. According to him there are three potentials in human soul. First, the vegetable nafs, that is, the man who has physical needs of eating and reproduction. Food is a human need. Second, the animal nafs is, the main perfection for the physical from the understanding aspect toward parts and some movement which move themselves. Third, the rational or human soul, that is perfection for the physical body while doing work according to choise, consideration, conclusion of the mind, and from the aspect of assumption of the common things.

This nafs has potential, namely the potential of practical reason and the potential of theoretical reason. The potential of practical reason always encourages one to choose what is worth to be done or abandon, or it is called moral behavior. The potential of theoretical reason, is the potential reason, the reason of acquisition, the actual reason and as the talent.

These potentials do not stand by themselves but they work together. These potentials lead and serve each other for all the potential of soul. Each potential soul serves one another. Then, the potential of talent serves the potential of actual reason, and the potential of material reason serves the potential of talent. Thus, IbnSina's concepts related to the physical and nonphysical dimensions of the human being, in which the nafs is a critical factor

${ }^{24}$ M. Yasir Nasution, “Telaah Signifikansi Konsep Manusia Menurut al-Ghazālī”, on jurnal Miqot, Volume XXXV, Nomor 2, (Juli-Desember, 2011), p. 236-237.

${ }^{25}$ Ibid., p. 237-238. 
in encouraging the body to live. Nafs is the main perfection for the body. The nafs is a separate core from the body. Ibn Sina understood that the nafs is eternal. When the body is destroyed, the nafs is eternal because it is part of the essence of eternal of God or The Everlasting of God. ${ }^{26}$

The concept of human based on Islam also comes from the Muslim thinkers of our archipelago, Nurcholis Madjid. According to him man is the culmination of God's creation. Among them, the most perfect creatures of God are human beings. The man will still occupy his honor as the best of beings and will not degenerate into the lowest creature if he believes and works righteously.

Primordially, it means the incident before birth, man is good (ahsan al-taqwim). Because, according to the Qur'an, man is bound by agreement with God (before birth), ie that man will recognize God as his protector. Later its form is, first, the attitude of worshiping to God; and second, good behavior. Therefore, human beings are born as holy beings.

The manifestation of human weakness among other is because of the biological insistence to survive (survive). Man's perception of good or bad, true or false is a dictation of his biological needs. That is called vested interest tyranny, which in Arabic is called lust nafs (hawanafs). Hawa means it self. There is the possibility of human to get failure to see the truth and goodness which will make it in holiness. Man's perception of good-bad, absolutely wrong is nothing more than a continuation of his vested interests. That is where people will always fail to seek the truth. Therefore, people need God's help by praying sincerely, show us the straight path. ${ }^{27} \mathrm{Oh} \mathrm{God}$, show me the way, because I do not know, I have no power to know it. So, the best we can pray is when we can really pure concentrate on God. ${ }^{28}$

According to Madjid, various statements in the Holy Scriptures affirm the position of human beings as the highest creatures of God, but at the same time creatures that have such potential to become the lowest. The creation of human beings as the highest is in accordance with the intent and purpose of becoming khalifah (literally means following from behind "vice/representative or substitute) on the earth, with the task of carrying out the "mandate"of God leads him to build the world as well as possible.

${ }^{26}$ Syah Reza, "Konsep Nafs Menurut Ibnu Sina”, on Jurnal Kalimah, Volume 12 Nomor 2, (September 2014), p. 271-277.

${ }^{27}$ QS. Al-Fatihah: 6.

${ }^{28}$ Budhy Munawar Rachman, Ensiklopedi Nurcholis Madjid, (Bandung: Mizan, 2006), p. 1817-1818. 
Therefore, as Caliph (Khalifah), man will be asked for his duty or his responsibility to carry out the" mandate "of God. ${ }^{29}$

2. The Mufassir Group

One of the leaders of the mufassir who criticized the Marxist concept of humanity through his interpretation was Hamka. Based on the meaning of the verses of the holy Qur'an, Hamka criticizes Marx's thinking which views man as only a material being and it is not a creation of God. As he interprets the QS. al-Baqarah: 177. According to Hamka, Marx's thought is not based on belief in God, nor does his belief about soul, soul or human spirit. Marx understood that human beings are material creatures so that the basic human which needed to be met in Marx's view is his biological physical need, it is not the need of his soul. Thus, manner and morality issues are as the most basic needs of human soul are ignored. ${ }^{30}$

Hamka says that Marx's teachings emphasize on material rather than religion, morals and ethics as the basic needs of the human soul. Man, according to Marx is not idealistic human, but real human, material, concrete, has body, which is objective, and it is not abstract. Marx's teachings place man as an animal whose life is determined by matter. ${ }^{31}$

According to Hamka, Marx's historical materialism is inspired by the theory of Charles Darwin's materialism which assumes humans are from the Apes. Hamka says that according to the information of the holy Qur'an, man is not the descendants of the Apes. ${ }^{32}$ According to the holy Qur'an, man is the most noble creation of God and for this, man is entrusted as caliph (Khalifah). Man is from heaven, then sent down to the earth to worship God. ${ }^{33}$

Besides Hamka, the mufassir which based on the Qur'anic message, understands that man is God's creation which occupies a special position in this universe. Man is the representative of God on the earth, as stated in the Qur'an QS. Al-Baqarah: 30: "Remember when your Lord said to the angels:" Verily I will make a caliph in the earth.

The meaning of the word khalifahdoes not bring differences of opinion among the mufaasir. According to Ibn Kasirr, khalifah is the head of

\footnotetext{
${ }^{29}$ Ibid., p. 1826.

${ }^{30}$ Hamka, Tafsir al-Azhar, Jilid. I, Juz. 2, (Jakarta: Pustaka Panjimas, 1982), p. 71.

${ }^{31}$ Hamka, Keadilan Sosial dalam Islam, (Jakarta: Gema Insani, 2015), p. 152.

${ }^{32}$ Hamka, Dari Hati Ke Hati, (Jakarta: Gema Insani, 2016), p. 38.

${ }^{33}$ Ibid.,
} 
the government of the Muslims. ${ }^{34}$ Similar views are also presented by alQurtubi ${ }^{-35}$. Different with al-Wahidi ${ }^{36}$ and al-Syaukāni ${ }^{37}$ Both of them tend to limit the khalifah as leaders of the Prophets which take turn to uphold the law of God. While al-Fairuzabadi from Ibn 'Abbas ${ }^{38}$ and al-Zamakhsyari ${ }^{39}$ saw the position of the khalifah including the position of kings and prophets as the government. ${ }^{40}$ Besides, human position as a mustakhlif on the earth, the Qur'an also reveals the position of man as a musta'mir. That is the creator of prosperity. The basis of this statement is Allah's word in the holy Qur'an, the surah QS. Hūd: 61. The verb ista'mara is an expression that indicates the human position. This verb is formed from another verb, namely عر. This word consists of the letters' ain, mim, and ra. The significance of these letters, "eternity and long period of time, and something rising" (like sounds or other)..$^{41}$ The morphological analysis of this word is amara-ya'muru meaning lexical "longevity, wealth, inhabited, make long life. ${ }^{42}$ From the description above, it is understandable that عمر is prosperous as an attempt to improve.

The pronunciation of $ع$ with all its forms is found 28 times in the holy Qur'an. ${ }^{43}$ According to QuraishShihab, the Qur'an in some Surah use ya'muru twice, each in QS. al-Taubah (9): 17-18. In this surah, the word "ya'muru" is related to the word mosque. It means prospering the mosque t.th.), p. 32 .

${ }^{34} \mathrm{Abū}$ al-Fidā Ismail Ibn Kasiir, Tafsīr al-Qur'an al-'Az̄īm, Juz IV (t.tp: al-Haramain,

${ }^{35}$ Abū 'Abdillāh Muhammad Ibn Aḥmad al-Qurțubī, Al-Jami' Li Ahkām al-Qur'an, Juz.XV (Mesir: Dār al-Katib al-'Arabī, 1976), p. 188.

${ }^{36}$ Abū al-Ḥasan Ibn Ahmad al-Wahidī, Asbāb al-Nuzūl, Ju II (Mesir: Mustafa al-Bāb al-Halabi, 1386/1986), p. 228.

${ }^{37}$ Muhammad ibn Ali Muhammad al-Syaukani, Al-Fath al-Qadir, Juz I (Bairūt: Dār al-Fikr, t.th.), p. 429.

${ }^{38}$ Abū Tahīr Muhammad ibn Ya'qūb al-Fairuzabadi, Tanwīr al-Miqbas Min Tafsīr ibn Abbas, (Beirūt: Dār al-Fikr, t.th.), p. 282.

${ }^{39}$ Mahmud ibn 'Umar al-Zamakhsyari, al-Faiq fí Garib al-Hadis, Juz III (Mesir: Dār al-Fikr, 1399), p. 371.

${ }^{40}$ Abd. Muin Salim, Konsepsi Kekuasaan Politik dalam al-Qur'an Cet. II, Jakarta: Grafindo Persada, 1995), p. 116.

${ }^{41}$ Lihat Ibn Faris Abī al-Husain Ahmad Ibn Faris, Mu'jam Maqāyis al-Lugat, Juz IV (Cet. I; Bairū Dār al-Fikr, t. th.), p. 140-141.

${ }^{42}$ Ibrahim Anis, (et.al), al-Mu'jam al-Wasit, Juz II Cet. I, (Beirūt: Dār al-Fikr, t.th), p. 632. See Lois Ma'luf, al-Munjid fi al-Lugah wa al-Adab wa al-'Ulūm (Bairūt: Katulikiyat, t.th), p. 592.

${ }^{43}$ Muhammad Fu'ad Abdul Bāqi, Mu'jam al-Mufarras Li al-Fāz al-Qur'an al-Karīm (Cet. II; T.t.: Dār al-Fikr, 1981/1401), p. 482-483. 
by building, maintaining, cleaning and i'tikaf. While QS. al-Rūm (30): 9 uses the last word 'amaru added with ard. It means making a building and managing it for its benefits. ${ }^{44}$ Quraish Shihab explains, the word isti'mara in surah 61 QS. Hūd consist of the letters sin and ta 'which is same with ista'lafa which means "ask forgiveness". The two letters can also mean "to make" as in the word hajar which means "stone", when it is combined with sin and ta so it is readable istahraja whose meaning is to be stone. ${ }^{45}$ Based on those meanings above, the term ista'marakum means "making you" or "asking/commanding you" to manage the earth / land to get benefit from it. The surah هو أنشأكم من الأرض و استعركم في explains that it is God who makes man and gives him the power to inhabit and manage the earth.

Abd Muin Salim ${ }^{46}$ understood that surah 61 QS. Hūd affirmed about human function as developer, builder and creator. This can be understood from the explanation of this verse that man was created from this earth and made the inhabitants who work on it for prosperity. All the facilities and materials which are on the earth are spread wide, provided for humans. Of course, the materials disscussed here are not finished materials, but they all require management and processing. In this condition, human creativity is necessary.

Man must try to create something and build things from available materials by using the facilities which already given to him. To make it happen, God gave human capital in the form of knowledge, as implied in the surah QS. Al-Baqarah (2): 31. This science can be through experience and path of teachings (revelation), so that there are guidelines which regulate the good life with the guarantee of salvation in the world; and for a better life in eternal later days. As God's khalifah, man is given the freedom to manage this life well. ${ }^{47}$ But it should be noted that the freedom is not absolute because as God's khalifah, it means removing the context of absolute human freedom. The man who has free desire can not determine himself, whether the ability that he brings from his birth from his propensities. The innate ability determines it when the nuṭah is formed. Thus, every human being

\footnotetext{
${ }^{44}$ Quraish Shihab, Membumikan Al-Qur'an: Fungsi dan Peran Wahyu Dalam Kehidupan Masyarakat (Bandung: Mizan, 1992), p. 164.

${ }^{45}$ Quraish Shihab, Wawasan al-Qur'an, Cet.V (Bandung: Mian, 1997), p. 424.

${ }^{46} \mathrm{Abd}$. Muin Salim, "Hak Asasi Manusia dalam Al-Qur'an", dalam Islam dan Perdamaian Global, ed. Azhar Arsyad dkk, (Yogyakarta: Kerjasama IAIN Alauddin Makassar, TAF, Madyan Press, 2002), p. 25.

${ }^{47}$ QS. Al-Baqarah: 284.
} 
has a provision when his death, can not be shortened or extended time. On the other hand, the essence of God's khalifah gives meaning that man frees himself from all types of serfdom other than to God. In Islam, man does not give up to follow the materialist tendencies. Man does not give himself to dahr which completely eliminating his creativity because understanding God gives human freedom which has characteristics different from other creatures besides humans.

Then, it appears that man has a free will that requires him to see how these characteristics are connected with contrast characteristics. The fact of rejection and the inflammation of the existence of God gives meaning of human biological tendencies which may be able to satisfy the fulfillment of all freedom that may be prevented. But to declare the freedom of human desire, it must always refer to equally unsustainable consequences. Man's faith to Allah as the Almighty is on this earth, from Adam's departure from heaven to this world. Human freedom has been struggles in order to test its duties and obligation. Islam explains that each human can behave individually, this individuality is reflected in the surah QS. Maryam: 95: And every one of them shall come unto Allah on the Day of Resurrection on its own.

It should be noted that human responsibility is not limited to merely visible behavior, even the psychological attitudes that usually precede birth behavior. The intention to act or not to do things shows a picture of a particular practical impression that is consideration part of his behavior, and from here he is entitled to a reward or punishment. ${ }^{48}$

Thus, his responsibilities still remain in the behavior of birth and his intention to perform certain acts. Individually, it may be actually ordered to consider the purpose to be taken, whether to positive action or otherwise to the negative.

The recognition of individualistic responsibility does not mean that it has no relation with anyone else. Humans who live in the center of society, always have to pay attention to other members of society. His responsibility to organize this interaction can be done. when restricting his participation to positive contributions, therefore if it is possible to avoid similar effects with other negative elements it would be possible to penetrate into his life. Besides, it is the responsibility of the individual to try to get out from bad

${ }^{48}$ QS. Al-Baqarah: 284. 
action, if not at least to take negative attitudes toward the bad action, or avoid them altogether.

There are three words used by the holy Qur'an to refer to humans.

1. Use a word consisting of alif, nun, and sin such as insān, ins, nās, or unās.

2. Using the word basyar.

3. Using the words Banī Adam, and zuriyat Adam

Many surah of the holy Qur'an which use the term bashyar to demonstrate that the process of human creation became basyar, through the stages until reaches the stage of adulthood. "And among the signs, the sign of His power (Allah) created you from the ground, then when you promised your basyar scattered ". (Surah al-Rūm: 20).

Spread here can be interpreted as prolific sex or scattered search for rezeki (sustenance). These two things can only be done by people who have maturity and responsibility.

Thus, it is seen that basyar associated with maturity in one's life and make it able to assume responsibility. Therefore, the mandate of khalifah is charged to basyar. ${ }^{49}$ The word insān comes from the root of the word uns which means docile, harmonious, and visible. This opinion, if it is viewed from the perspective of the holy Qur'an, it is more appropriate than those who think that it was taken from the word nasiya (forgot), or nasa-yanusu (shake).

The scriptures, the holy Qur'an, according to Bint Al-Shathi 'as revealed by QuraishShihab, often show the word insān with jin / jan. The jin are spirits that can not be seen clearly or invisible, whereas man is a real being.

The word man, according to Quraish Shihab, is used by the Qur'an to refer to man with his totality, soul and body. Humans are different from one person to another, due to physical differences, mental and intelligence. ${ }^{50}$

Besides Allah created man, Allah also made man live in pairs. This purpose is for the survival of the descendants of the human kind. In this case, Islam only sets a method, that is marriage. The surah of the Qur'an which discusses about it include QS. al-Nahl: 1: "God made for you wives of your kind and made for you from your wives, children and grandchildren, and

${ }^{49}$ Perhatikan surat al-Hijr; 28 yang menggunakan kata basyar, dan QS. Al-Baqarah: 30 yang menggunakan kata khalifah, yang keduanya mengandung pemberitaan Allah kepada malaikat tentang manusia.

${ }^{50}$ M. Quraish Shihab, Wawasan al-Qur'an..., h. 278-280. 
gave you sustenance from the good. So why do they believe in the vanity and deny the favors of Allah." 51

Regarding to potential of human, it has been discussed by the Qur'an. There are some surah/verses that praise and glorify human beings, for example, the explanation of the creation of man in the best possible form, ${ }^{52}$ and the statement about the glorification of human beings compared with other creatures of God, ${ }^{53}$ but often humans get censured by God because human beings are persecuting and denying favors, ${ }^{54}$ complained $^{55}$ and miserly. ${ }^{56}$

This does not mean that the Qur'an verses contradict one another, but these verses show some human weaknesses that must be avoided. Besides indicating that humans have the potential to occupy the highest position and respectable or be in a low place so that he is disgraceful. From this explanation, it is clear that man is a creature with the unity of two basic elements, which can not be separated, because when they are separated, it is not human anymore. ${ }^{57}$

\section{Conclusion}

From the description above about human concepts according to the perspective of Marxism and Muslim thinkers, it can be concluded that there are several thoughts of Marxism about human which is different and criticized by Muslim thinkers. The most fundamental criticism of Muslim thinkers on the Marxist concept of humanity is that the concept of Marxism is built on material and economic grounds and denies the existence of supernatural things such as God and religion.

The criticism of Muslim thinkers on the concept of Marxism about man, that man should not be seen only from the existence of differences in material condition. According to them, people and society are strongly influenced by transcendent relationship such as God and religion, which Marxism strongly denied. The essence of man and society in their view can not be separated from his relationship with God and religion, it is not merely

\footnotetext{
${ }^{51}$ Lihat pula QS. An-Nisā: 1, al-Syura: 11; al-Nabā: 8.

${ }^{52}$ QS Al-Tīn: 5.

${ }^{53}$ QS Al-Isrā: 70.

${ }^{54}$ QS. Ibrāhim: 34.

${ }^{55}$ QS. Al-Ma'ārij: 19.

${ }^{56}$ QS. Al-Ma'ārij: 19.

${ }^{57}$ Ibid., h. 282.
} 
material-based, but rather a connection with God's power and will. So, the basic conception of Muslim thinkers is not partial, but includes other factors. This makes most fundamental difference between human concepts according to Marxism and Muslim thinkers. [] 


\section{BIBLIOGRAPHY}

Bāqi, Muḥammad Fu'ad Abdul, Mu'jam al-Mufahras Li al-Fāz al-Qur'ān alKarīm, Cet. II, T.t.: Dār al-Fikr, 1981/1401.

Achmad, Firdaus, "Marxisme dan Islam, Bagaimana Manusia diperikan?" dalam Khatulistiwa: Journal of Islamic Studies, Volume 3, Nomor 2, September 2013.

al-Anșāri, Jamaluddīn ibn Hisyām, Mugnī al-Labīb, jilid I, t.tp: Syarikat Nār al-Ṡaqāfat al-Islāmiyat, t.th.

al-Fairuzabadi, Abū Tahīr Muḥammad ibn Ya'qūb, Tanwīr al-Miqbās Min Tafsīr ibn Abbas, Beirūt: Dār al-Fikr, t.th.

Al-Ghazālī, Mizan al-'Amal, Kairo: Dār al-Ma'ārif, 1961.

al-Qurțubī, Abū 'Abdillāh Muhammad Ibn Aḥmad, Al-Jami' Li Aḥkām alQur'an, Juz.XV, Mesir: Dār al-Katib al-'Arabī, 1976.

al-Syaukani, Muḥammad ibn Muḥammad Ali ibn Muḥammad, Fath al-Qadīr al-Jami' Baina al-Riwāyah wa al-Dirāyah min 'Ilm al-Tafsirr, Juz II, Cet. I: Bairūt Dār al-Kutūb al-Ilmiyah, 1994/1415.

, Fath al-Qadīr al-Jami' Baina al-Riwāyah wa al-Dirāyah min 'Ilm al-Tafsīr, Juz I, Bairūt: Dār al-Fikr, t.th.

al-Waḥidī, Abū al-Ḥasan Ibn Aḥmad, Asbāb al-Nuzūl, Juz II, Mesir: Mustafa al-Bāb al-Halabi, 1386/1986.

al-Zamakhsyari, Maḥmud ibn 'Umar, al-Faiq fi Garib al-Hadïs, Juz III, Mesir: Dār al-Fikr, 1399.

Anis, Ibrāhim, (et.al), al-Mu'jam al-Wasiț, Juz II Cet. I, Beirūt: Dār al-Fikr, t.th.

Anis, Lois, al-Munjid fi al-Lugah wa al-Adab wa al-'Ulūm, Bairūt: Katulikiyat, t.th.

Bakker, Anton, Antropologi Metafisik, Yogyakarta: Penerbit Kanisius, 2000.

Bekker, Anton \& Zubair, Achmad Charis, Metodologi Penelitian Filsafat, Yogyakarta: Kanisius, 2000.

Fromm, Erich, Konsep Manusia Menurut Marx, Judul asli: Marx’s Concept of Man, terj. Agung Prihantoro, Yogyakarta: Pustaka Pelajar, 2002.

G. Mayer, Cf. Alfred, Marxisme: The Unity of Theory and Practice, Cambridge: Harvard University Press, 1954

Giddens, Anthony, Kapitalisme dan Teori Sosial Modern, Jakarta: UI-Press, 2007.

Gould, Carol C., Marx's Social Ontologi, New York: The Massachutsetts Institute of Technology, 1978. 
Hamka, Keadilan Sosial Dalam Islam, Jakarta: Gema Insani, 2015. , Tafsir al-Azhar, Jilid. I, Juz. 2, Jakarta: Pustaka Panjimas, 1982. , Dari Hati Ke Hati, Jakarta: Gema Insani, 2016.

Ibn Faris, Abū al-Ḥusain Aḥmad, Mu'jam Maqāyis al-Lugat, Juz IV, Cet. I; Bairūt Dārl-Fikr, t. th.

Ibn Kasiī, Abū al-Fidā Ismail, Tafsīr al-Qur'an al-Ażīm, Juz IV, t.tp: AlHaramain, t.th.

Marx, Karl, Capital: A Critical Analysis of Capitalis Production, Vol. I, Moscow: Foreign Langues Pubishing House, 1959.

Marx, Karl, On Economis, ed. Robert Freedman, Victoria, Penguin Books, 1962.

Marx, Engels, on Religion, Moscow: Foreign Langues Publishinng House, 1957.

Nasution, M. Yasir, "Telaah Signifikansi Konsep Manusia Menurut alGhazālī”, dalam jurnal Miqot, Volume XXXV, Nomor 2, JuliDesember, 2011.

Rachman, Budhy Munawar, Ensiklopedi Nurcholis Madjid, Bandung: Mizan, 2006.

Ramli, Andy Muawiyah, Peta Pemikiran Karl Marx, Materialisme Dialektis dan Materialisme Historis, Yogyakarta: Lkis, 2004.

Reza, Syah, "Konsep Nafs Menurut Ibnu Sina”, Jurnal Kalimah, Volume 12 Nomor 2, September 2014

Ritzer, George, Goodman, Douglas J., Teori Sosiologi, dari Teori Sosiologi Klasik sampai perkembangan Mutakhir Teori Post Modern, terj. Nurhadi, Yogyakarta: Kreasi Wacana, 2008

Salim, Abd. Muin, "Hak Asasi Manusia Dalam Al-Qur'an", dalam Islam dan

Perdamaian Global, ed. Azhar Arsyad, dkk, Yogyakarta: Kerjasama IAIN Alauddin Makassar, TAF, Madyan Press, 2002.

, Konsepsi Kekuasaan Politik dalam al-Qur'an, Cet. II, Jakarta: GrafindoPersada, 1995.

Sastrapratedja, M., Manusia, Teka-Teki yang Mencari Solusi, edt: A. Setyo Wibowo, Yogyakarta: Penerbit Kanisius, 2009.

Shihab, Quraish, Membumikan Al-Qur'an: Fungsi dan Peran Wahyu Dalam Kehidupan Masyarakat, Bandung: Mizan, 1992. , Wawasan al-Qur'an, Cet. V, Bandung: Mian, 1997.

Tim Lintas Media, Kamus Al-Akbar Arab-Indonesia, Indonesia-Arab, Jombang: Lintas Media, 2002. 
Ilyas Daud, Bermawy Munthe dan Ahmad Baidhowi

Peuresen, C.A. Van, Licham-Ziel-Geest, Inleiding tot een Wijsgerige Antropologie, Terjemahan Dick Hatoko. Tubuh Jiwa Roh, Sebuah Pengantar Dalam Filsafat Manusia, Jakarta: BPK GunungMulia, 1981.

Wadaya, Baskara T., Marx Muda: Marxisme Berwajah Manusia, Yogyakarta: Buku Baik, 2003. 